\title{
Õpianalüütika võimalused õppimise ja õpetamise toetamisel õpetajahariduses
}

\author{
Kaire Kollom $^{\text {a1 }}$, Kairit Tammets ${ }^{\mathrm{b}}$ \\ ${ }^{a}$ Tallinna Ülikooli haridusteaduste instituut \\ ${ }^{b}$ Tallinna Ülikooli digitehnoloogiate instituut
}

\begin{abstract}
Annotatsioon
Info- ja kommunikatsioonitehnoloogia rakendamine ning õpihaldussüsteemide ja õpikeskkondade kasutamine õppeprotsessis on muutnud õpetajaks õppijate õpikogemusi ning õpetajahariduse õppejõudude õpetamisviise. Sellega kaasnevad erinevad digitaalsed andmed, mis annavad õppijale, õpetajale ning õppekava eestvedajale tagasisidet õppimise ja õpetamise tõhustamiseks. Haridusvaldkonnas aina enam rakendust leidev õpianalüütika võimaldab suurendada õppijate teadlikkust ja tõhusust õppeprotsessis, individualiseerida õppeprotsessi ning saada pidevat ja jooksvat tagasisidet õppimise edenemise kohta. Artikli eesmärk on analüüsida õpetajahariduse üliõpilaste ja õppejõudude ootusi õpianalüütika võimaluste suhtes, et toetada õpikeskkonnas õppimist ja õpetamist. Uurimuse teoreetilise raamistiku loob ennastjuhtiva õppija kontseptsioon. Uurimistulemused baseeruvad disainipõhisel uurimusel, kus osalusdisaini sessioonide käigus selgitati välja õpikeskkonna kasutajate (üliõpilaste, õppejõudude, õppekavade juhtide) ootused õpikeskkonna õpianalüütikarakenduste suhtes.
\end{abstract}

Võtmesõnad: õpianalüütika, ennastjuhtiv õppija, õpikeskkond, õpetajakoolitus, õppejõud

\section{Sissejuhatus}

Üha kiiremini arenev õpianalüütika valdkond hõlmab õppijate ja nende tegevuste kohta käivate andmete analüüsimist, et anda informatsiooni õpetamisja õppimispraktika ning õpikeskkondade parendamiseks (Long \& Siemens, 2011). Bichsel (2012) on öelnud, et seniste õpianalüütikauuringute eesmärk on olnud pakkuda akadeemilistele töötajatele andmeid õppijate soorituse kohta

Haridusteaduste instituut, Tallinna Ülikool, Uus-Sadama 5, 10120 Tallinn; kaire.kollom@tlu.ee 
peamiselt selleks, et õppijad ei katkestaks õpinguid haridusasutuses. Samas on viimasel ajal püütud uuringutega välja selgitada, kuidas saaks õpianalüütikat kasutada, et anda õppijatele õpianalüütika töölaudade kaudu otsest tagasisidet (Verbert, Duval, Klerkx, Govaerts, \& Santos, 2013), kuigi endiselt on ka selles liinis lünkasid, nt tuleks paremini mõista õpianalüütikast tuleneva tagasiside kasulikkust õppija perspektiivist.

Macfadyen, Dawson, Pardo ja Gašević (2014) on öelnud, et automatiseeritud analüütika pakkumine õppijatele ja õppejõududele eesmärgiga anda tagasisidet selle kohta, milline on õppija käitumine õpisituatsioonis, tema areng ja õpiväljundite saavutatuse tase, ei toeta üksnes õppijate akadeemilisi sooritusi, vaid kujundab ka nende enesereguleeritud õppimise oskusi, mida peetakse akadeemilise edukuse üheks märkimisväärseks näitajaks. Need õppijad, kes on madalamate akadeemiliste näitajatega, on ka vähem võimekad oma võimete hindamisel ning oma õpioskuste analüüsimisel (Kruger \& Dunning, 1999). Samas on uuringud näidanud, et õppijate motivatsioon ning valmisolek end jälgida on seotud nende õpingute kvaliteedi, edasijõudmise ja akadeemiliste saavutustega (Dunlosky \& Thiede, 1998). Tagasiside pakkumine õppijatele, et toetada enesereguleeritud õppimist, on ka praeguse artikli fookuses. Butleri ja Winne (1995) kohaselt on tagasiside võtmeelement õppijate enesereguleeritud õppimine, kuna see toetab õppijaid oma arengu jälgimisel ning strateegiate kohandamisel, võimaldades saavutada seatud õpieesmärke.

Siinse artikli eesmärk on selgitada välja õpetajahariduse üliõpilaste ja õppejõudude ootused ning vajadused selliste õpianalüütika töölaudade järele, mis toetaksid õpetajahariduse üliõpilaste ennastjuhtivat õppimist. Peale üliõpilaste ennastjuhtiva õppimise on fookuses ka õppejõud, kes saavad üliõpilasi õppeprotsessis toetada, kuid kõigepealt tuleb välja selgitada, millist tuge õppejõud selleks ise vajavad. Kolmandaks soovitakse artikliga saada esmast teavet selliste õpianalüütika lahenduste väljatöötamiseks, mis võimaldaksid anda jooksvat automatiseeritud tagasisidet õpitegevuste kohta, rõhutades indiviidi ja rühma arengut ning kasutades ära õpikeskkondades õppimise käigus tekkivaid andmeid. Need aga pakuksid õppekava kontekstis omakorda tagasisidet õppekava rakendamise kohta ja looksid hea aluse arendustegevuseks.

Artikli tarbeks tehtud uuringus otsiti vastuseid järgmistele uurimisküsimustele.

1. Millised õpianalüütika töölaua infograafikud on õpetajahariduse üliõpilaste ennastjuhtiva õppe toetamiseks tähenduslikud?

2. Kuidas tajuvad õpetajahariduse õppejõud õpianalüütika töölaua infograafikuid üliõpilaste ennastjuhtiva õppimise toetamise vahendina?

3. Milliseid võimalusi pakuvad õpianalüütika töölaua infograafikud liikumiseks Eesti õpetajahariduses tõenduspõhise sekkumise suunas? 


\section{Õpianalüütika töölauad enesereguleeritud õppimise ja otsuste tegemise toetajana}

Õpianalüütika vahendite väljatöötamisel on oluline toetuda õppimise teoreetilisele käsitlusele. Kuigi õpianalüütika mõiste sisaldab seost sõnaga õppimine, on tegelikult väga mitmed õpianalüütika lahendused välja töötatud andmetest lähtudes ja ilma tugeva seoseta õppimisega. Tänapäeva teadmuspõhises ühiskonnas on enesejuhitud ja -reguleeritud õppimine muutunud üha olulisemaks professionaalses arengus ning elukestvas õppes, mistõttu on enesejuhitud õppimine valitud ka siinse töö pedagoogiliseks raamistikuks.

Durall ja Gros (2014) on öelnud, et kirjanduses kasutatakse termineid enesejuhitud óppimine (ingl self-directed learning) ning enesereguleeritud õppimine (ingl self-regulated learning) tihti sünonüümidega, kuna nendel põhinevatel mudelitel on väga palju sarnasusi: mõlemas mudelis rõhutatakse õppija aktiivset osalemist õppeprotsessis ning oluline on eesmärgistatud käitumine. Erinevus kahe mudeli vahel seisneb selles, et enesejuhitud óppimises on peale isikuomaduste fookuses ka õpikeskkonna omadused (Loyens, Magda, \& Rikers, 2008). Kui enesereguleeritud õppimist on uuritud peamiselt akadeemilises kontekstis, siis enesejuhitud õppimise mõiste põhineb täiskasvanud õppija kontseptsioonil, mis on seotud pigem mitteformaalse keskkonnaga (Durall \& Gros, 2014). Praeguses uurimuses on kasutatud mõisteid enesejuhitud õppimine ning enesereguleeritud óppimine samatähenduslikena.

Kooskõlas mitmete enesereguleeritud õppimise mudelitega ning konstruktivistliku õppimisega oleme võtnud seisukoha, et õppijad on agendid (Jonassen, 1991), kes otsivad ja teevad valikuid oma eesmärkide saavutamiseks. Eneseregulatsiooni tähtsus õppimisel on ilmselge (Bransford, Brown, \& Cocking, 2000), kuid mõista, kuidas see on rakendunud konkreetses olukorras, ei ole lihtne ülesanne. Üldiselt teatakse, kuidas hinnata õppija teadmisi, oskusi ja tulemusi, aga interpreteerida ja hinnata tegevuste kvaliteeti, strateegiaid, eesmärke ning laiemalt reguleerimist on palju keerukam (Roll, Wiese, Long, Aleven, \& Koedinger, 2014).

Viimastel aastatel on hakatud (sh Eestis) üha suuremat tähelepanu pöörama selliste veebipõhiste keskkondade disainimisele, mis toetavad õppijate enesereguleeritud õppimist: oma õpieesmärkide seadmist, õpitegevuste planeerimist, sobivate vahendite ja strateegiate valimist jne. Näiteks võimaldab LeContract õppijal seada oma õpieesmärke (Väljataga, Tammets, \& Põldoja, 2011) ja veebipõhine lahendus EduFeedr koondada blogipõhiseid kursusi, pakkudes õppijale tagasisidet tema edenemise kohta (Põldoja, Duval, \& Leinonen, 2016a). Lisaks on Põldoja jt (2016b) uurinud õpimärkide kasutamist kõrghariduses eesmärgiga toetada óppijatele tagasiside andmist. Laanpere jt (2014) on pakkunud välja prototüübi Dippler, mis toetab õppijate enesejuhitud õppimist, 
pädevuste arendamist, koostöist ühisloomet ning ülesandepõhist õpidisaini. Need näited eneseregulatsiooni toetavate lahenduste kohta, mida on õpetajahariduses katsetatud, on heaks lähtekohaks, et toetada enesereguleeritud õppimist digitaalses keskkonnas. Siit edasi peaks nii uurimis- kui ka arendustegevuses keskenduma sellele, kuidas kasutada loodud lahendusi süsteemselt õppijate tagasisidestamisel ja enesereguleeritud õppimise oskuste kujundamisel. Õpianalüütika töölauad on üks peamisi võimalusi selle elluviimiseks. Oma erinevate infograafikutega võimaldavad need digitaalses õpikeskkonnas anda õppijale õppeprotsessis tagasisidet ning toetada tema eneseregulatsiooni. Samuti pakuvad töölauad võimalusi sekkuda õppeprotsessi, muuta õpitegevusi ning teha otsuseid õppetöö kohta.

Verbert jt (2013) on andnud aastate eest ülevaate õpianalüütika töölaudade senistest ja tulevastest võimalustest, analüüsides viitteist töölauda järgmiste näitajate alusel: sihtrühm (õpetajad, õpilased), kogutud andmed (kulunud aeg digitaalsete õppematerjalide kasutamiseks, sotsiaalne interaktsioon, materjalide ja töövahendite kasutamine, materjalide loomine, ülesannete ning testide tulemused), andmete kogumise võimalused (sensorid, mikrofonid, kaamerad, süsteemi andmefailid jms), kasutatud seadmed (sülearvutid, mobiilsed seadmed) ning tulemuste hindamine (kasutatavus, kasulikkus, efektiivsus jms). Analüüsi tulemusena eristati kolme tüüpi töölaudu: 1) töölauad, mis toetavad traditsioonilist kontaktõpet ülikoolis; 2) töölauad, mis toetavad traditsioonilist rühmatööd; 3 ) töölauad, mis pakuvad võimalusi kujundada teadlikkust õppimisest ja reflekteerimise pädevusi, mõtestada õppimist ning muuta käitumist veebipõhises või kombineeritud õppes (ibid.).

Mingil määral on uuritud ka eri tüüpi töölaudade mõju õppimisele. Näiteks ilmneb Arnoldi ja Pistilli (2012) uuringust, et nendel õppijatel, kes pääsesid ligi oma õpianalüütika töölaudadele, paranesid õpitulemused ning nad saavutasid paremaid tulemusi ülikooliõpingute jätkamisel. Samas võib selle uuringu kitsaskohaks pidada asjaolu, et ei ole kirjeldatud, kuidas üliõpilased töölaudade infograafikuid interpreteerisid ja tagasisidele vastasid ning millist mõju see avaldas õppijate õpistrateegiatele ja motivatsioonile (Corrin \& de Barba, 2014). Corrini ja de Barba (2014) uuringu tulemused illustreerivad, kuidas üliõpilased, kel oli ligipääs õpianalüütika töölaudadele, näitasid üles võimet reflekteerida ja planeerida oma õppetööd. Lisaks mõjusid töölauad üliõpilastele motiveerivalt aine läbimisel ning tagasiside toetas neid õppeprotsessi tegevuste elluviimisel ja hindamisel (ibid.). Uuring Suurbritannias näitab, et need üliõpilased, kes kasutasid õpianalüütika lahendusi oma saavutuste ja tulemuste võrdlemiseks teiste omadega, said 1,92 korda suurema tõenäosusega tulemuseks vähemalt C kui need, kes ei kasutanud võimalust end võrrelda (Sclater, Peasgood, \& Mullan, 2016). Siiski on puudu uuringutest, mis näitaks, kuidas töölaudade kasutamise tulemusel muutub õpetamisprotsess ning milliseid muudatusi on 
õppejõud teinud kursuste disainis. Pole tõendeid, millised õpianalüütika abil visualiseeritavad muutujad on pedagoogiliselt tähenduslikud (Macfadyen \& Dawson, 2010). Ka Verbert jt (2013) kinnitavad, et senised uuringud ei anna piisavat ülevaadet õpianalüütika töölaudade efektiivsusest ning esineb piiranguid, kuidas mõõta töölaudade abil õppijate käitumise muutumist, kuna selline evalveerimine eeldab terviklikku ning korduvaid parandusi, samuti longituuduuringuid.

Eelnevale lisaks on uurimata valdkond õpianalüütika töölaudade süsteemne kasutamine õpetajahariduses mikro- (tulevaste õpetajate eneseregulatsiooni väljatöötamine), meso- (õppekava arendamine ja õppedisaini parandamine) ja makrotasandil (ülikooli ja riigi tasandi otsuste tegemine) ning õppekavaarenduses toetava komponendina. Õppejõudude ja õpetajate töölaudasid on arendatud mitmeid, aga neid kasutatakse peamiselt kursuste tegevuste analüüsimiseks mikrotasandil ning parimal juhul leiavad muutused aset ühe kursuse piires. Samas pakuvad õpianalüütika andmed tohutut potentsiaali rikastada õppekavaarendust ning saada lisatagasisidet seni domineeriva süsteemi kohta, kus tudengitel palutakse hinnata üksikuid kursusi. Wolf (2007) on rõhutanud, et õppekavaarendus peab lähtuma andmetest ning vaja on õppekava süsteemset hindamist, mille tulemusel tehakse õppekavas muudatused. Ühe sellise lähenemisviisi on välja pakkunud Pata jt, (2016), leides, et õppekavaarendus koosneb kolmest omavahel seotud tsüklist: 1) õppekavaarendusega seotud normdokumentide (kutsestandardite, riiklike normdokumentide) küpsemine (maturing); 2) õppekava küpsemine ning 3) personaalsete pädevuste küpsemine. Õppijate digitaalsed jäljed loovad hea lähtekoha õppekavaarenduseks, mis omakorda mõjutab valdkondlike normdokumentide arendamist (ibid.).

Seega võib öelda, et hariduses liigutakse üha enam selle poole, et õppijate kasutatavad keskkonnad pakuks õppimise ja õpetamisega seotud sidusrühmadele tagasisidet ning võimaldaks kujundada enesereguleeritud õpioskusi, mida vajatakse tänapäeva teadmuspõhises ühiskonnas.

\section{Metoodika}

\section{Uuringu disain}

Uuringu eesmärk on välja selgitada ootused õpetajahariduse õpikeskkonna eDidaktikumi õpianalüütika lahenduse loomiseks Tallinna Ülikooli õpetajahariduse õppekava üliõpilaste, õppejõudude ja õppekava juhtide kaasabil. Kuna üliõpilased ja õppejõud on eDidaktikumi peamised kasusaajad ja kasutajad, otsustati nad kaasata analüütikalahenduse väljatöötamisse ning seetõttu valiti uuringu- ja disainiprotsessi aluseks disainipõhise uurimuse raamistik (Barab \& Squire, 2004), mida siinses uurimuses tutvustatakse. Disainipõhine uuring on 
süstemaatiline ja paindlik protsess, mille eesmärk on parandada hariduslikku praktikat iteratiivse analüüsi, disaini, arendamise ja rakendamise kaudu, tuginedes teooriast lähtuvale koostööle uurijate ja praktikute vahel. Üliõpilaste ja õppejõudude kaasamine praegusse uuringusse võimaldab mõista sügavamalt uuringu konteksti ning tagada osalejad, kellega saab iteratiivselt uuringut läbi viia. Uuringus toetutakse ka osalusdisainile, mida on mitmetes õpianalüütika uuringutes esitatud kui sobivat strateegiat disainiprotsessis (Knight, Brozina, Stauffer, Frisina, \& Abel, 2015). Osalusdisaini puhul lähtutakse põhimõttest, et kasutajad on kõige õigemal positsioonil, et öelda, kuidas toetada ja parandada nende tööd. Sellega pööratakse traditsiooniline disaineri-kasutaja suhe tagurpidi, vaadates kasutajat kui eksperti ja disainerit kui tehnilist konsultanti (Schuler \& Namioka, 1993). Oluline on kaasata üliõpilased uuringusse, et saada teada nende ootused ja vajadused ning leida viise, kuidas nende õppeprotsessi toetada. Ülikooli kaasamine õppejõudude ja õppekavade juhtide kaudu võimaldab välja selgitada võimalused, kuidas ülikool saaks üliõpilastele tagasiside andmist rohkem toetada ning kuidas kasutada kogutud andmeid õppekavaarenduses. Ootuste ja vajaduste väljaselgitamine enne reaalsete lahenduste väljatöötamist aitab tagada lahenduste vastavuse kasutajate prioriteetidele (Park \& Jo, 2015).

Uuringu etapid on planeeritud järgmised: vajaduste väljaselgitamine, prototüüpide väljatöötamine, prototüüpide katsetamine ja evalveerimine õpetajahariduse sidusrühmadega, paranduste tegemine süsteemis, süsteemi rakendamine jne. Tammets ja Laanpere (2015) on välja selgitanud kolme õpetajahariduse didaktika õppejõu esialgsed ootused eDidaktikumi õpianalüütika lahenduse suhtes. Praeguses uuringus minnakse sellest üks etapp edasi ning ootuste väljaselgitamisesse on kaasatud süsteemselt õppekavade erinevad osalised.

\section{Valim}

Lähtudes uurimuse eesmärgist kaasata õpetajahariduse eri sidusrühmi õpianalüütika lahenduste disainiprotsessi, korraldati esimesed disainisessioonid nende eDidaktikumi kasutajatega, kes on keskkonnas õppetööd läbi viinud ja õppetöös osalenud. Esimesel disainisessioonil, kus osalesid Tallinna Ülikooli õpetajahariduse üliõpilased, õppejõud ning õppekavade arendamise ja rakendamise eest vastutajad (edaspidi: õppekavade juhid), keskenduti peamiselt ootuste ja vajaduste väljaselgitamisele.

Üliõpilaste puhul oli tegemist juhuvalimiga, uuringus osalemine oli vabatahtlik. E-posti teel saadetud kutse osaleda disainisessioonil edastati alushariduse ja klassiõpetaja õppekava tudengitele ning uuringusse kaasati vaid need õppijad, kellel oli võimalik etteantud ajal disainisessioonil osaleda. Õppe- 
kavade valik tulenes sellest, et nende kahe õpetajakoolituse õppekava tudengeid õpetatakse haridusteaduste instituudis alates bakalaureuseõpingute algusest. Õpianalüütika lahenduse ja ka uuringu seisukohalt ei olnud oluline, kas üliõpilane õpib bakalaureuse- või magistriõppes.

Õppejõududest kaasati uuringusse kõik vastutavad õppejõud, kes puutuvad kokku alushariduse ja klassiõpetaja õppekavadega, ning õppekavade juhid. Kuna Tallinna Ülikoolis ei ole üliõpilastel ega õppejõududel seniseid kogemusi õpianalüütikaga, ei olnud võimalik uuringusse kaasata neid osalejaid, kellel oleksid olnud vajalikud varasemad teadmised või kogemused.

Disainisessioonidel osalesid sidusrühmad eraldi, et võimalikult täpselt välja selgitada iga rühma ootused ja vajadused. Õpetajahariduse tudengeid oli kaasatud uuringusse üheksa (kuus bakalaureuse- ja kolm magistriastme üliõpilast) ning õpetajakoolituse erialaainete ja didaktika õppejõude viis. Lisaks osales uuringus viis õpetajakoolituse õppekava juhti. Uuringus osalejate arv on pigem tagasihoidlik, samas on osa autoreid väitnud, et tarkvaralahenduste disainimisel on 5-12 osaleja kaasamine protsessi piisav, et välja selgitada vajalik info, ning liiga palju osalejaid võib anda vastupidise efekti (Beyer \& Holtzblatt, 1998; Hackos \& Redish, 1998; Kujula \& Mäntylä, 2000).

\section{Andmete kogumine ja analüüsimine}

Et selgitada välja lõppkasutajate ootused õpianalüütika lahenduste suhtes, korraldati kaheksa osalusdisainil põhinevat disainisessiooni: kolm sessiooni üliõpilastega (ühes rühmas magistrandid ja kahes rühmas bakalaureuseõppekavade tudengid), kolm õppejõududega ja kaks õppekavade juhtidega. Disainisessioonide käigus tehtud intervjuude pikkus oli 49-83 minutit.

Kõikidel disainisessioonidel kasutati abimaterjalidena ekraanitõmmiseid eri õpikeskkondade ja õpihaldussüsteemide (Moodle, EduFeedr, eDidaktikum, EMMA) õpianalüütika võimalustest, mida näidati osalejatele. Ekraanitõmmiste eesmärk oli illustreerida erinevaid õpianalüütika võimalusi ning seeläbi suunata osalejaid analüüsima, kuidas visualiseeritud andmed võiksid õppeprotsessi toetada. Ekraanitõmmiste kasutamine oli vajalik peamiselt seetõttu, et uuringus osalejad ei olnud õpianalüütika valdkonna võimalustega tuttavad. Seetõttu võis eeldada, et uurija küsimustele vastamine võib olla raskendatud, kui puudub arusaam asjakohastest võimalustest. Näiteks kui disainisessioonil arutati, kas õpianalüütika lahendus peaks võimaldama õppijal võrrelda oma arengut kursuse jooksul teiste õppijate omaga, siis näidati osalejatele sarnaseid lahendusi õpikeskkondades, kus õppijatel on võrdlemisvõimalus olemas.

Disainisessiooni ajal kasutatud küsimused olid jagatud plokkidesse, millest valik on esitatud tabelis 1. 
Tabel 1. Disainisessioonidel kasutatud intervjuuküsimuste seosed uurimisküsimustega (näited)

\begin{tabular}{|c|c|c|}
\hline $\begin{array}{l}\text { Küsimuste } \\
\text { plokk }\end{array}$ & Küsimus & Seotud uurimisküsimus \\
\hline $\begin{array}{l}\text { Ennastjuhtiv } \\
\text { õppimine }\end{array}$ & $\begin{array}{l}\text { 1. Mil määral peate õppijana oluliseks } \\
\text { näha oma arengut kursusel } \\
\text { õpianalüütika lahenduse toel (soori- } \\
\text { tatud ülesanded, läbitud materjalid, } \\
\text { osaletud vestlused)? } \\
\text { 2. Milliseid otsuseid võimaldaks teil } \\
\text { teha visualiseeritud ülevaade aren- } \\
\text { gust oma õppimise kohta? } \\
\text { 3. Milliseid tegevusi planeeriksite, kui } \\
\text { teil oleks võimalus saada tagasisidet } \\
\text { õppija edenemisest ainekursusel } \\
\text { võrdluses teiste õppijatega? }\end{array}$ & $\begin{array}{l}\text { Millised õpianalüütika töölaua } \\
\text { infograafikud on õpetaja- } \\
\text { hariduse üliõpilaste ennast- } \\
\text { juhtiva õppe toetamiseks } \\
\text { tähenduslikud? } \\
\text { Kuidas tajuvad õpetajahariduse } \\
\text { õppejõud õpianalüütika töö- } \\
\text { laua infograafikuid üliõpilaste } \\
\text { ennastjuhtiva õppimise toeta- } \\
\text { mise vahendina? }\end{array}$ \\
\hline $\begin{array}{l}\text { Koostöös } \\
\text { õppimine }\end{array}$ & $\begin{array}{l}\text { 1. Kui te näeksite oma kursuse kohta } \\
\text { sellist vaadet, mille kohaselt osa } \\
\text { õppijaid ei ole grupi interaktsioonis } \\
\text { (foorumi vestlused, blogide kom- } \\
\text { menteerimine) aktiivsed, siis kas ja } \\
\text { milliseid sekkumisviise te planeerik- } \\
\text { site kursusel rakendada? } \\
\text { 2. Millisena soovite saada õpikesk- } \\
\text { konnast tagasisidet õppijate } \\
\text { omavahelise interaktsiooni kohta } \\
\text { õpiülesannete sooritamisel? }\end{array}$ & $\begin{array}{l}\text { Kuidas tajuvad õpetajahariduse } \\
\text { õppejõud õpianalüütika töö- } \\
\text { laua infograafikuid üliõpilaste } \\
\text { ennastjuhtiva õppimise toeta- } \\
\text { mise vahendina? }\end{array}$ \\
\hline Pädevused & $\begin{array}{l}\text { 1. Kui oluliseks peate õppijana saada } \\
\text { ülevaade, milliste pädevuste } \\
\text { omandamist eri kursuste } \\
\text { ópitegevused toetavad? } \\
\text { 2. Milliseid tegevusi planeeriksite, } \\
\text { kui näeksite keskkonnast, et teie } \\
\text { õppekava tudengitel on teatud } \\
\text { pädevused jäänud õpingute käigus } \\
\text { omandamata, või kui näeksite, et } \\
\text { teie õppekava kursused kujun- } \\
\text { davad vaid sarnaste pädevuste } \\
\text { omandamist? } \\
\text { 3. Kuidas mõjutab õppetöö } \\
\text { planeerimist ja läbiviimist võimalus } \\
\text { näha õppija isiklike eesmärkide } \\
\text { saavutatust? } \\
\text { 4. Milliseid tegevusi planeeriksite, } \\
\text { kui näeksite aine eesmärkide ja } \\
\text { õpiväljundite seotust õppekava } \\
\text { eesmärkide ja õpiväljunditega? }\end{array}$ & $\begin{array}{l}\text { Millised õpianalüütika töölaua } \\
\text { infograafikud on õpetaja- } \\
\text { hariduse üliõpilaste ennast- } \\
\text { juhtiva õppe toetamiseks } \\
\text { tähenduslikud? } \\
\text { Milliseid võimalusi pakuvad } \\
\text { õpianalüütika töölaua info- } \\
\text { graafikud liikumiseks Eesti } \\
\text { õpetajahariduses tõendus- } \\
\text { põhise sekkumise suunas? }\end{array}$ \\
\hline
\end{tabular}


Disainisessioonide käigus saadud andmeid analüüsiti kvalitatiivse sisuanalüüsi meetodil eesmärgiga kirjeldada õpetajahariduse üliõpilaste, õppejõudude ja õppekavade juhtide ootusi ning vajadusi seoses õpianalüütika võimaluste kasutamisega eri õpikeskkondades. Kvalitatiivne sisuanalüüs annab disainiuuringus võimaluse osalejate seisukohti analüüsida sobiva raamistiku järgi, milleks praeguse uuringu kontekstis oli ennastjuhtiv õppimine (Krippendorff, 2006). Disainisessioonidel salvestatud intervjuude tekstist koostati pärast transkribeerimist tervik, kust korduva läbilugemise käigus märgistati kõige olulisemad märksõnad ja kontseptsioonid (koodid). Esimeses analüüsietapis kirjeldati õpetajahariduse üliõpilaste, õppejõudude ning õppekavade juhtide ootusi ja vajadusi seoses õpianalüütika töölaudadega, mis toetaksid ennastjuhtivat õppimist. Teises analüüsietapis võimaldasid leitud sarnaste koodide grupid luua induktiivsel teel põhikategooriad, mis jagunesid järgmiselt: enesejuhitud õppimine ja autonoomia, koostöine õppimine ning pädevused ja pädevuspõhine õppimine. Uurimistulemuste analüüsis kasutatakse teksti ilmestamiseks näiteid disainisessioonide käigus tehtud intervjuudest.

\section{Tulemused}

\section{Õpianalüïtikast tulenevad õppijate ootused ja vajadused ennastjuhtiva õppimise toetamisel}

Tänapäeva õpetajahariduses puutuvad üliõpilased kokku paljude keskkondadega. Õppeinfo asub õppeinfosüsteemis (ÕIS), mis on eri ülikoolidel erinev, kuigi üliõpilased võivad läbida kursuseid mitmes Eesti ülikoolis. Õppetöö toimub eri keskkondades: õpihaldussüsteemis Moodle, õpikeskkonnas eDidaktikum, avatud õpikeskkondades ajaveebide vahendusel jm. Uuringus osalenud üliõpilased leidsid, et õpikeskkondade puhul on oluline, et kasutataks läbivalt ühte või mitut omavahel seotud ning informatsiooni ja andmeid vahendavat õpikeskkonda, et pakkuda õppijale tema õpingute edenemisest terviklikku ülevaadet ja analüüsi. Seda peavad óppijad oluliseks just oma eri- ja kutsealaga seotud eesmärkide ning pädevuste kontekstis, kuna nii saavad nad tagasisidet, mille alusel on võimalik kavandada edasisi õpinguid ja professionaalset arengut.

Oma tegevusest ülevaate saamiseks pidasid uuringus osalenud óppijad vajalikuks infograafikuid, mis annaksid õpikeskkonnas ülevaate kursuse ajalisest kulgemisest ja selle seosest õppejõu määratud tähtaegadega ning kujutaksid seost kulutatud aja ja aine tulemuse vahel. Samuti oli uuringus osalenud õppijate jaoks tähtis saada ülevaade jooksva perioodi ópingutest. Õppekava rakendamisel pidasid osalejad oluliseks, et õpingute käigus tehtavad ülesanded ja sooritused jaotuksid õppeperioodi jooksul võimalikult ühtlaselt ning 
õpikeskkonnast oleks võimalik saada pidevat ja jooksvat ülevaadet oma pädevuste kujunemisest eriala ja kutsepädevuste kaupa.

... praegu on kõik [eksamid ja arvestused] ühe nädala peal koos ning peab kõike teadma korraga ja on ainult üks teadmiste katsumise periood.

Õppijate arvates peaksid rakendatavad õpianalüütika võimalused olema ennetava loomuga ja andma tagasisidet, samuti peaksid need võimaldama muuta õpikäitumist jooksvalt, mitte õppeperioodi lõpul (nt semestri või aine lõpp). See viitab asjaolule, et õppijad ei näe õpianalüütikat karistava vahendina, mis sekkub õppetöösse hilja, vaid pigem toetava vahendina, mis sekkub õppetöösse ning suunab õppijat oma õppimise eest vastutust võtma.

Õppejõud kasutavad praegu õpikeskkonda pigem materjalide üleslaadimiseks ja üliõpilane peab sinna esitama oma ülesanded. Sageli on nii, et esitad kõik oma ülesanded ja siis saad lõpuks aine hinde, aga mitte sisulist tagasisidet. Üliõpilased ju suhtlevad omavahel ja tagasiside on tihti täpselt ühesugune kõikidel.

Kasutatavate õpikeskkondade puhul ootavad õppijad võimalust isikustada õpikeskkonda ning seda ka tagasiside saamisel. Näidetena tõid õppijad välja võimalused kujundada õpikeskkonnas omanäoline kasutajakonto või ajaveeb.

Mulle meeldiks isegi seda valida, millisena ma tagasisidet saan ... Et ma saaksin näiteks valida, et kui mul on halb tulemus, siis saan valida, millise pildina seda mulle näidatakse ...

Väga olulisena rõhutasid uuringus osalenud õppijad vajadust saada mitmesugust tagasisidet. Õppijate jaoks on tähtsal kohal õppejõu sisuline, asja- ja ajakohane ning hindamiskriteeriumitest lähtuv tagasiside, mis soodustab õppimist ja õpikäitumise muutumist. Ideaalis soovivad uuringus osalenud üliõpilased õppejõududelt personaalset tagasisidet oma edenemise kohta. Samas hinnatakse sellist tagasisidet ajamahukaks ning mõistetakse selle vähesust.

Praeguse uurimuse üks eesmärke oli välja selgitada, mida arvavad õppijad võimalusest näha eriala, kutse, õppekava, aine, ülesande, tulemuse jms tasandil oma edenemist ning võrrelda seda teiste õppijate omaga individuaalsel või rühmatasandil (ehk samal kursusel osalejate omaga). Uuringus osalenute arvates võib võrdlus teiste õppijatega mõjutada õppija õpikäitumist sõltuvalt õppija enesejuhitavusest kas positiivses või ka negatiivses suunas. Sisemiselt motiveeritud, vastutustundlikule ja sihikindlale õppijale võib see anda ülevaate oma edenemisest ning vajaduse korral ka infot enam pingutust nõudvate teemade ja ülesannete kohta (Kui sa ikka näed, et sa teistest kehvem oled, võib 
mõnel jalad alt ära lüüa. Mõnd sunnib see aga just pingutama ...). Teisalt võib võrdlus teiste õppijatega mõjutada oma õpingute alguses olevat ja teistest sõltuvamat õppijat negatiivselt ning tekitada temas ebaõnnestumise ja ka käegalöömise tunde.

Kui inimene [üliõpilane] on selle piiri peal, et kas ta üldse jätkab õpinguid, siis temal võivad olla erinevad tunded neid asju vaadates. Aga ega sellest ei saa ka täielikult lähtuda, sest kõik ei olegi mõeldud ülikooli lõpetama ...

Uuringust selgus, et sageli kasutavad õppejõud eri õpikeskkondi hoidlana õppematerjalide jagamiseks. Õppijate arvates on õpianalüütika võimaluste rakendumise ja õppimise toetamise eeldus veebipõhise õpikeskkonna eesmärgipärane kasutamine ehk õpikeskkond peab võimaldama eri õpiülesannete tegemist. Ülevaadet õppematerjalidest, mida kaasõppijad on õpikeskkonnas kasutanud, uuringus osalenud üliõpilased oluliseks ei pidanud, põhjendades seda ennastjuhtiva õppija suutlikkusega ise sobivaid ja vajalikke õppematerjale leida.

Jagatud info iga õppija individuaalse edenemise kohta pakub uuringus osalenud üliõpilaste arvates võimalust toetada kaasõppijat, mis samas võib omakorda suurendada õppija sõltuvust kaasõppijaist või õppejõust ega toeta ennastjuhtiva õppija kujunemist. Kokkuvõtlikult jäid uuringus osalenud õppijad seisukohale, et võimalus võrrelda oma edenemist teistega võib õpikeskkonnas olla, kuid säilima peab ka võimalus see funktsioon oma töölaual välja lülitada (Sest siis need, kes ei taha näha, need ongi nagu jaanalinnud pea liiva all ... Nii, nagu ta oma ülesanded tegemata jättis, nii ta livva all istubki ...). Oluliseks pidasid aga õppijad võimalust võrrelda enda soorituse lõpptulemust aines osalenute keskmise tulemusega normaaljaotuse kõveral, mis annaks õppijate arvates olulist tagasisidet ka õppejõule, et teha õppeprotsessis vajalikke muudatusi. Lisaks selgus uuringust, et kaasõppijate õpiülesannete soorituse info ei mõjuta õppijate otsust, keda ta valib enda kaaslaseks koostööd nõudvate edasiste õppeülesannete tegemisel. Põhjendusena toodi välja, et tehtud ülesanne ei anna ülevaadet soorituse kvaliteedist ning ülesannete tegemata jätmisel võivad olla objektiivsed põhjused. Olulisemaks peeti väljaspool õpikeskkonda toimuvat suhtlust.

Minu jaoks on ikka otsustamisel oluline, millised on minu suhted ja senised kogemused teise üliõpilasega ... Tal [üliõpilasel] võis olla lihtsalt halb päev või juhtus midagi ... No ja see, et tal on ülesanded alati tehtud, ei tähenda, et need on hästi tehtud ... Ja ega see ka ei mõjuta mu valikut, sest tulemused ei ole alati tähtsad ...

Õpikeskkonnas suhtlemist võimaldavate vahendite ja võimaluste rakendamisel võimaldab õpianalüütika saada ülevaate sotsiaalsest võrgustikust õpikesk- 
konnas. Uuringus osalenud õppijate arvates ei ole sotsiaalvõrgustiku analüüs õpikeskkonna kontekstis tähtis. See annab õppejõule parema ülevaate ülesannete sooritatuse, mitte sotsiaalse suhtlemise kohta. Olulise märkusena toodi ka välja, et suurem osa suhtlusest leiab aset väljaspool õpikeskkonda või muudes sotsiaalvõrgustikes, nt Facebook, Skype.

Õpikeskkonnas me oleme ju ainult siis, kui ma pean mingeid ülesandeid tegema ... Ega sealt seda õiget infot küll ei saa ... Ma isegi ei kirjuta sageli õppejõule küsimusi sinna ... Me ikka arutame omavahel seda ja mitte seal [õpikeskkonnas] ...

Õppijate tagasiside võimaluste analüüsimiseks uuriti õppijate valmisolekut anda pärast sooritamist eri õpiülesannetele kulunud aja ja tunnetusliku raskusastme kohta enesehinnang kvantitatiivsete näitajate kujul. Uuringus osalenud üliõpilaste arvates annaks see hea võimaluse õppijail analüüsida õpiülesannetele kulunud aja, tunnetusliku raskusastme ning õpiülesande tulemuse seoseid. Samuti pakuks see tagasisidet õppejõule õpiülesannete tunnetusliku raskusastme ja mahu kohta. Nii õppija kui ka õppejõu vaates võimaldab see analüüsida õppimist ja õpetamist ning teha vajalikke muudatusi.

\section{Õpianalüütikast tulenevad õppejõudude ootused ja vajadused ennastjuhtiva õppimise toetamisel}

Õpianalüütika vahendite ja võimaluste rakendamisel on õppejõudude arvates tähtis välja selgitada, milline on õppijate valmisolek analüüsida keskkonnast saadavat tagasisidet, kuidas on õppekavasse integreeritud õppija professionaalse arengu toetamine ning kuidas kavandada tegevusi õpioskuste arendamiseks.

Õpimotivatsiooni kohta käiv tagasiside, mida juurutatakse, sobiks pigem ópikeskkonda ainekursuste juurde, mitte abstraktselt ... See on ikka meeletu kunsttükk seda muidu pärast nii kasutada, et sellest kellelegi kasu oleks ...

Uuringus osalenud õppejõud peavad oluliseks, et õpikeskkond võimaldaks siduda omavahel õpiülesanded ja eriala- või kutsepädevused ning et õppija, õppejõud ja õppekava juht saaksid ülevaate õppijate pädevuste kujunemisest eriala või kutsestandardi kontekstis. Samuti on õppejõudude hinnangul väga tähtis suunata õppijaid sihipäraselt analüüsima oma kutsepädevusi ning viima ellu sellest lähtuvat eesmärgistatud tegevust. 
Teine teema on kutseoskuste teema ... See eeldab meilt, õppejõududelt, muidugi väga head koostööd ja oluline on, et igas aines oleks mingi ülesanne, kus nad tegelevad eneseanalüüsiga ... Me justkui tegeleme kõik mingite juppidega, aga me võiks mingil hetkel monitoorida, et milline see pilt tervikuna õppija vaates on ...

Samuti peavad uuringus osalenud õppejõud vajalikuks, et õpikeskkonda oleksid integreeritud lihtsad ja praktilised vahendid, mis soodustaks õpioskuste arendamist.

Kui õppija hilineb korduvalt oma õpiülesannete esitamisega, mis annab märku vajadusest efektiivsemalt oma aega planeerida, siis annab õpikeskkonda integreeritud tagasiside õppijale soovitusi ajaplaneerimise teemadel iseseisvaks lugemiseks, koolitusteks jne.

Lisaks tähtsustavad uuringus osalenud õppejõud, et õpikeskkonda oleks integreeritud automatiseeritud teavitused ópiülesannete tähtaegade ja sooritamise vajaduse kohta. Eriti oluliseks peavad õppejõud seda kõrghariduse esimese astme õppijate õpioskuste ja -harjumuste toetamisel. Siiski jäävad uuringus osalenud õppejõud arvamusele, et inimlik faktor ja nõustamissüsteem (tuutor, õppenõustaja, karjäärinõustaja jne) on õppijate õpioskuste arengu toetamisel äärmiselt olulised ning need ei tohi kaduda, vastupidi - neid tuleks tõhustada. Siin ei näe õppejõud vastuolu ennastjuhtiva õppimise põhimõtetega, vaid leiavad, et oluline on suunata õppija võtma vastutust oma õppimise eest, analüüsima enda arenguvajadusi ning püstitama neist lähtuvaid isiklikke eesmärke.

Kui ma näen, et rühmadünaamika läheb paigast ära, siis me ju arutame óppejõududega, et mida oleks vaja teha jne. Aga ma ei saa sekkuda üksinda. Küsimus on aga selles, et kui ma kellegi puhul näen mingit probleemi, et siis kuidas see on lingitud ülikooli nõustamissüsteemiga ... Kelle poole ma ta siis suunan ja kas üliõpilastele on võimalusi ... Kelle poole ma peaksin pöörduma, kes on see tuutor või nõustaja ...

Lahendustest, mis õppejõudude arvates toetaksid õppijate õppimist, pakuti välja võimalus integreerida õpikeskkonda erinevaid küsimustikke.

Mulle meeldiks need lahendused, et kohe kodutöö järgselt ... saaks esitada paar-kolm küsimust - millal sa tegid, kaua sa tegid, kas oled juba õppima hakanud jne -, mis juhiks õppija tähelepanu, et ta jätab asjad viimasele hetkele ... Läbi õpikeskkondade antavad küsimused annavad mulle õppejõuna infot, millal jne õppijad ülesandeid teevad, aga samas sunnivad ka üliõpilast ennast ja oma õppimist reflekteerima ... 
Uuringus osalenud õppejõudude arvates annavad olulist tagasisidet õppijatele õpimotivatsiooni perioodiline hindamine (nt enne ja pärast ainekursust) ning võimalus saada õpikeskkonnast tagasisidet oma õpimotivatsiooni, rahulolu, õpikäitumise ja õppetulemuste vaheliste seoste kohta. Samuti leiavad õppejõud, et iga õpiülesanne võiks saada enne esitamist õppijatelt hinnangu raskusastme ja kasutatud aja kohta, mis võimaldab õppijal reflekteerida oma õpikäitumist ning analüüsida selle seost tulemustega.

Sotsiaalsest suhtlemisest ülevaate saamine ei ole õppejõudude arvates õpikeskkonnas õppimise toetamisel vajalik. Küll aga soovivad õppejõud õpikeskkonnas näha tehnilist lahendust, mis võimaldab määrata koostööd või õppijatepoolset tagasisidet ning kasutada suhtlust nõudvate õpiülesannete puhul limiteerimist (nt vastuse kommenteerijate arv) ja eristamist.

Pigem on vaja seda, et keskkond pakuks automaatselt välja, kus ma olen pannud piirangud, kui palju peab üksteise ülesandeid õppimise eesmärgil tagasisidestama, siis keskkond annab mulle seda infot ... Kui mul on aines suur hulk $[150+]$ osalejaid, siis ei jõua kunagi ise seda kontrollida ...

Kuigi kõik uuringus osalenud olid ühel meelel, et pidev süsteemne ja sisuline eneseanalüüs peaks kaasnema iga õpiülesandega, lahknesid õppejõudude arvamused õpianalüütika lahenduste kohta, mis võimaldavad lasta õppijatel võrrelda enda tegevust (sooritusi, tulemusi jne) teiste õppijate omaga. Osa uuringus osalenud õppejõududest arvas, et see võib õppijaid motiveerida ning väline motivaator võib muutuda õpingute edenedes ka sisemiseks motivaatoriks.

Vastutus on õppimise eest eelkõige õppijal endal. Ta peaks saama enda kui õppija kohta profiilipildi ning võrdluse keskmisega ... Kui õppija saab vaadata, kas ta on keskmisest kõrgem või keskmisest madalam oma tulemustes ... See oleks selline motivatsiooninipp, et mida rohkem on õppijal informatsiooni oma õppimise kohta, seda lihtsam on tal seda planeerida ... Õppejõu vaates oleks hea näha, et on mingisugused õppijate profilid, ning ma saan õppetööd planeerides arvestada sellega.

Oli ka vastupidiseid arvamusi: leiti, et täiskasvanud ja ennastjuhtiv õppija peaks õppima enda jaoks, oma eesmärkide saavutamiseks, mitte ajendatuna võrdlusest teistega. Lisaks arvati, et avatud õpikeskkondades õppimisel ning teiste tegevuste nägemisel on suurem mudeldamise, loovuse kadumise ja plagiaadioht. Samuti leiti, et oluline on õppija võimalus saada tagasisidet iseenda õppimise kohta, võrrelda oma edenemist iseendaga ning planeerida oma õppimist.

Tahaks väga, et täiskasvanud õppija õpib enese pärast, mitte võrdluse pärast teistega ... Ja meil on neid juhtumeid olnud, et õppija näeb, kaasõppijal 
on ülesanded tehtud, vaadatakse tema pealt ... Eks see oht plagiaadiks on suurem ... Peaks ikka olema nii, et ma võrdlen iseennast iseendaga ... et ma olen parem, kui ma olin ... et ma õpingi ikkagi iseenda jaoks ...

Samas olid uuringus osalenud õppejõud seisukohal, et õpikeskkonnast peaks õppija ja õppejõud saama ülevaate õppijate edenemisest nii ainete kui ka õpperühmade (nt ühel õppekaval õppijad) kaupa, mis annaks õppijaile võimaluse analüüsida enda õppimist võrdluses õpperühmaga ning õppejõule vajaduse korral võimaluse rakendada nõustamissüsteeme (tuutor, õppekava juht jne). Nii nagu õppijad, pidasid ka uuringus osalenud õppejõud oluliseks võimalust rakendada õppeprotsessis mitmekesiseid võimalusi (sh hindamist) pakkuvat üht õpikeskkonda või eri õpikeskkondi, mis on üksteisega seotud ja/või vahetavad infot.

Meil on hästi palju erinevaid keskkondi, mida kasutatakse või peab kasutama ... Need peaksid omavahel suhtlema. Et kui ma panen nt eDidaktikumi tulemuse sisse, siis see läheb automaatselt õppeinfosüsteemi ka. Aga praegu on olukord, kus ma pean minema veel sinna ja ... kümnesse kohta. Tegelikult peaks olema e-keskkond see, mis toetab mind õppejõuna, aga hetkel tekitab pigem see tööd juurde ...

Õppejõudude arvates on õppimise toetamisel oluline, et õppijal oleks võimalik saada endast terviklik ja mitmekülgne ülevaade. See võimaldab õppijal tagasiside põhjal analüüsida oma õpioskusi ja -käitumist ning vajaduse korral planeerida neis muudatusi. Uuringus osalenud õppejõudude ühine arvamus oli, et õpikeskkonna kasutamine on õigustatud vaid siis, kui see toetab õppimist ja õpetamist, mitte ei too kaasa lisatööd.

\section{Õpianalüütikast tulenevad võimalused ja vajadused óppekava arendamise ja rakendamise toetamisel}

Õppekava arendamise ja rakendamise eest vastutajatele on tähtis saada õpikeskkonnast perioodilist ja pidevat tagasisidet õppijate pädevuste kujunemise kohta nii individuaalselt, aine, õpperühma kui ka kogu õppekava lõikes. Uuringus osalenud õppekavade juhtide jaoks on õppimise ja õpetamise toetamiseks oluline mitmekülgne tagasiside. Õppijate ja õppejõudude nimetatud lahendusi ja vahendeid peavad vajalikuks ka õppekavade juhid.

Minu jaoks on oluline, et kõik õppija kohta käivad andmed jookseksid kokku. Et kui õppeinfosüsteemis küsitakse tema õpimotivatsiooni kohta ning näiteks eDidaktikumis on tema ained, ülesanded ja tulemused, et siis need oleksid lingitavad, jookseksid kokku ... Ma saan vaadata ideaalis indi- 
viidipõhiselt, et küsitakse rahulolu, õpimotivatsiooni, õppekava jm kohta, ning need seostatakse andmetega, kas ta on ülesanded õigel ajal ära teinud, millisel tasemel ja mis ta tulemus lõpuks on ... Et mul [õppejõul] oleks võimalik need tulemused kokku viia nii grupi kui indiviidi tasemel ...

Uuringus osalenud õppekavade juhid peavad oluliseks tagasisidet õppekava rakendamisel kasutatavate õppemeetodite, õpiülesannete ja hindamismeetodite kohta, seda nii õppekava, ainete kui ka pädevuste puhul. Nad rõhutasid vajadust saada tagasisidet pädevuste kujunemisega seotud õpiülesannete ja õppemeetodite mahu kohta õppekava kontekstis.

Õppekava juhina sooviksin ma väga ülevaadet, et milliste pädevuste saavutamiseks milliseid ülesandeid tehakse ... Aine alguses õppejõud märgib ära, et selle pädevuse saavutamiseks teeb õppija seda ülesannet ja teise jaoks teist ... Ja oluline on, et õppija harjuks eneseanalüüsiga tegelema ...

Samuti olid õppekavade juhid arvamusel, et kuigi õppekava arendatakse ja planeeritakse eri huvirühmade (õppejõudude, õppijate, tööandjate) koostöös, siis õppekava rakendamisest ülevaate saamine on keeruline, mistõttu hinnati kõrgelt võimalust saada õppekava rakendamisel toetust õpikeskkonda integreeritud õpianalüütika lahendustest (Õppekava arendamise vaates kui näen, et mingid näitajad on pikema aja jooksul samad, siis kas pärast muudatusi on asjad positiivses või negatiivses muutuses ...). Seetõttu peab uuringus osalenud óppekava juhtide arvates õpikeskkond võimaldama (või isegi kohustama) õppejõul määrata aine seotus eriala, õppekava ja kutsestandardi õpiväljundite ja pädevustega ning leida nende saavutamiseks vajalikud õpimeetodid ja -ülesanded. Kuna uuringus osalesid õpetajakoolituse õppekavade õppejõud ja üliõpilased, siis õppekava juhtide arvamustes annab õpiülesande analüüs, mis tehakse eespool nimetatud seoste loomisel, õppijale vajalikud teadmised ja oskused õppeprotsessi kavandamiseks, mis on tulevase elukutse seisukohalt oluline pädevus.

Kokkuvõtlikult leidsid uuringus osalenud õppekavade juhid, et õpianalüütika lahendused looksid võimalused toetada õppimist ja õpetamist, parandada õppeprotsessi ning arendada õppekava.

\section{Õppija autonoomsust toetavad õpianalüütika lahendused õpikeskkonnas}

Ennastjuhtiva õppimise üks põhiomadusi on õppija autonoomsus, mis väljendub tema iseseisvas algatus-, otsustus- ja sooritusvõimes, sõltumatuses ning suutlikkuses planeerida järjepidevalt oma õppimise arengut. Uuringu tulemusena võib välja tuua õppijate, õppejõudude ja õppekavade juhtide vajadu- 
sed ja ootused seoses selliste õpianalüütika lahenduste ja võimalustega, mis toetavad õppija autonoomsust:

- õppija edenemise ülevaade ainete kaupa (joonis 1);

- õppija võimalus võrrelda oma õppimist (ülesannete sooritatus, õpiülesannete ja ainete tulemused) kaasõppijate omaga, võttes arvesse õppimise keskmisi õpperühmas;

- õppija tegevuste ülevaade ajalises järjestuses ja kogu aine kontekstis (ülesannete esitamine, õppematerjalidega tutvumine, aktiivsus õpikeskkonnas) (joonis 2);

- õpiülesannetele kulutatud aja, tunnetusliku raskuse ja lõpptulemuste vahelised seosed.

Joonisel 1 on kujutatud õppija edenemise ülevaade jooksval perioodil toimuvate ja juba lóppenud ainete kaupa. Iga aine puhul on näha aine sooritamise eelduseks olevate ülesannete sooritatus nii arvuliselt kui ka osakaaluna. Samuti saab õppija, õppejõud ja õppekava juht soovi korral näha õpikeskkonnas iga õppija personaalset infot ning võrrelda seda õpperühma keskmisega.

\section{eDidaktikum Dashboard News Events Resources Groups Contact}

\section{Dashboard}

Dashboard Portfolio Files Tasks Blog Shared with me Learning Analytics

\section{My active Courses}

GRR7112 Seminaire de master

Õpetaja kui uurija

Meediakasvatus kaugõpe III

Haridustehnoloogia praktika

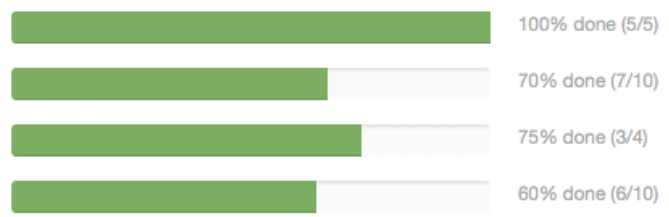

\section{My Completed Courses}

Magistritöö seminar I

$100 \%$ done $(5 / 5)$

Joonis 1. Õppija edenemise ülevaade jooksval perioodil toimuvate ja juba lõppenud ainete kaupa 


\begin{tabular}{|c|c|c|c|c|c|}
\hline Aeg & $\begin{array}{l}\text { Kasutaja } \\
\text { täisnimi }\end{array}$ & $\begin{array}{l}\text { Möjutatud } \\
\text { kasutaja }\end{array}$ & Sündmuse kontekst & Komponent & Sündmuse nimi \\
\hline $\begin{array}{l}29 \\
\text { okt } \\
11: 16\end{array}$ & & - & Fail: Ülesanne & Fail & $\begin{array}{l}\text { Kursusemoodulit } \\
\text { on vaadatud. }\end{array}$ \\
\hline $\begin{array}{l}29 \\
\text { okt } \\
11: 14\end{array}$ & & - & $\begin{array}{l}\text { Fail: Vahendiga õppemängu ja juhendi } \\
\text { tulemused }\end{array}$ & Fail & $\begin{array}{l}\text { Kursusemoodulit } \\
\text { on vaadatud. }\end{array}$ \\
\hline $\begin{array}{l}29 \\
\text { okt } \\
11: 12\end{array}$ & & - & $\begin{array}{l}\text { Kursus: Mäng ja lapse areng } \\
\text { (tsükliõpe) }\end{array}$ & Süsteem & $\begin{array}{l}\text { Kursust on } \\
\text { vaadatud. }\end{array}$ \\
\hline $\begin{array}{l}29 \\
\text { okt } \\
11: 12\end{array}$ & & - & $\begin{array}{l}\text { Ülesanne: Ülesanne } 3 \text { - Esitlus } \\
\text { MÄNGUASI. MÄNG JA MÄNGIMINE } \\
\text { ALTERNATIIVPEDAGOOGIKATES. }\end{array}$ & Ülesanne & $\begin{array}{l}\text { Esitatud töó } \\
\text { olekut on } \\
\text { vaadatud. }\end{array}$ \\
\hline
\end{tabular}

\begin{tabular}{|c|c|c|c|c|}
\hline $\begin{array}{l}29 \\
\text { okt, } \\
11: 11\end{array}$ & - & Fail: Rühmatöö juhend & Fail & $\begin{array}{l}\text { Kursusemoodulit } \\
\text { on vaadatud. }\end{array}$ \\
\hline
\end{tabular}

Joonis 2. Õppija tegevuste ülevaade Moodle'i keskkonnas

Joonisel 2 kujutatud õppija tegevuste ülevaade on ajalises järjekorras ja tegevuste kaupa. Õppijate arvates annab tegevuste ülevaate graafiline esitus põhjalikuma tagasiside tema õpikäitumisele.

\section{Koostöist õppimist toetavad õpianalüütika lahendused}

Kõik uuringus osalenud õppijad, õppejõud ja õppekavade juhid leiavad, et koostöine õppimine on suurepärane õppimisressurss. Samas õppimise toetamisel nad sotsiaalse suhtlemise ülevaadet oluliseks ei pea ning sellest rohkem väärtustatakse tehnilisi lahendusi:

- koostööd eeldavate ülesannete puhul võimalust limiteerida osalejate arvu, nt foorumis algatatud temaatilise arutelu korral võimalus määrata tagasiside andjate ja vastajate arv;

- võimalust õpikeskkonnas eristada koostööd nõudvate elementidega ülesandeid õppijate edenemise vaates, nt kasutades erinevaid värve.

Võimalik on integreerida õpikeskkonda ka tagasiside saamine õppijate omavahelisest interaktsioonist (suhtlus foorumites, ülesannete vaatamine jne), mida ilmestab joonis 3, kuid uuringus osalenud seda õppimise toetamisel oluliseks ei pidanud. 


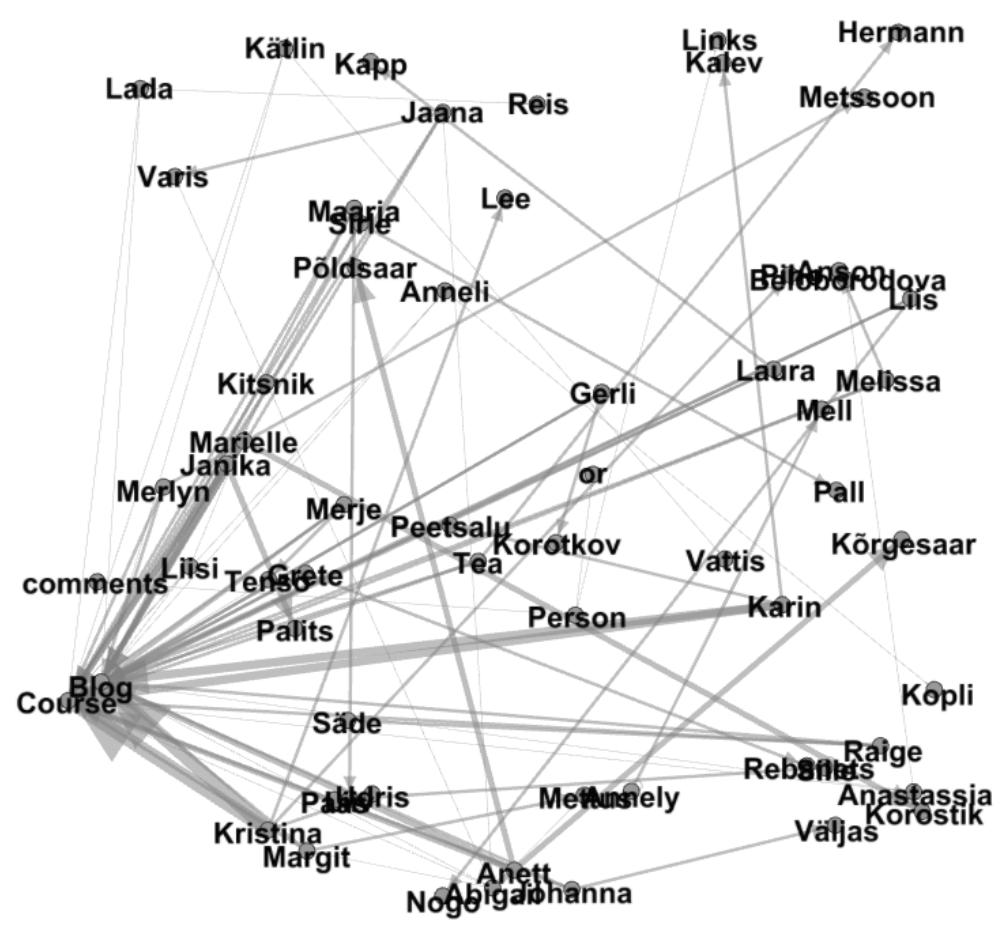

Joonis 3. Sotsiaalse võrgustiku ülevaade õpikeskkonnas

\section{Õppija pädevuste kujunemist toetavad õpianalüütika lahendused õpikeskkonnas}

Õppija pädevuste kujunemise ülevaadet ning võimalust võrrelda seda õpperühma keskmisega pidasid uuringus osalenud väga oluliseks nii õppimise, õpetamise, õppeprotsessi planeerimise kui ka õppekava arendamise ja rakendamise seisukohalt. Õpianalüütika lahendustega seotud ootused on järgmised: - õpikeskkonnas aine loomisel aine õpiväljundite sidumine eriala/kutsestandardi pädevuste ning aines sooritatavate ülesannetega;

- jooksva perioodi ainekursuste edenemise ülevaade ning selle võrdlus rühma keskmisega (joonis 1);

- võimalus näha õppija pädevuste kujunemist nii individuaalselt, õpperühma kui ka õppekava lõikes (joonis 4).

Joonisel 4 on kujutatud üks viis saada ülevaade õppija edenemisest õpetaja kutsestandardi pädevuste kaupa. Samuti on võimalik saada ülevaade iga pädevuskategooria all esitatud tegevusnäitajatest ja alategevuste sooritamiseks esitatud ülesannetest ning sooritatuse tasemest. 


\section{Dashboard}

Dashboard Portfolio Files Tasks Blog Shared with me Learning Analytics

Learning Analytics - Competency profile (full)

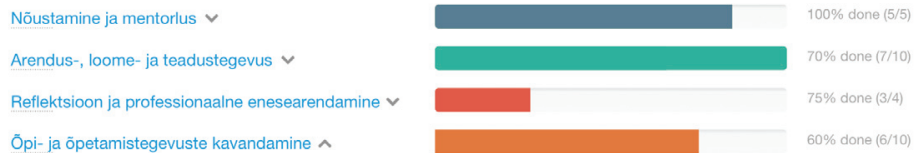

Ōpl- ja öpetamistegevuste kavandamine ^

Pädevus

Selgitab vălja rühma ja ôppija ainealase taseme, öpioskuste ja ôpimotivatsioni teseme ning arvestab neid ainevaldkondlike,

üldpedagoogiliste ja kasvatuslise eesmärkide seadmisel, toetudes ōppekavale; tunneb ära haridusliku erivajaduse ja kaasab vajadusel

tugispetsialisti öpikeskkonna tingimuste muutmiseks; valmistab ette arenguvestluse

\begin{tabular}{|l|l|l|}
\hline$\#$ & Pädevuse tükk & Evidence \\
\hline 1 & Selgitab valja rühma ja ooppija ainealase taseme & http://edidaktikum.ee/content/tunni-vaatlusjuhis- 0 \\
\hline 2 & Selgitab välja rühma ja õppija õpisoskuste ja ōpimotivatsiooni taseme & http://edidaktikum.ee/content/tunni-vaatlusjuhis-0 \\
\hline
\end{tabular}

Õpikeskkonna kujundamine $\checkmark$

Öppimise ja arengu toetamine $\checkmark$

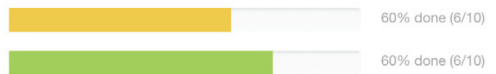

Joonis 4. Õpetaja pädevuste kujunemise ülevaade alapädevuste kaupa

\section{Arutelu}

Uurimistulemustest selgus, et nii üliõpilased, õppejõud kui ka õppekavade arendamise ja rakendamise eest vastutavad õppekavade juhid peavad kasutatavate keskkondade puhul kõige olulisemaks, et õpikeskkonnad ja õppeinfosüsteemid oleksid omavahel seotud ja vahetaksid andmeid. Kõikide uuringus osalenud sihtrühmade jaoks on tähtis, et õpikeskkond toetaks õppimist ja õpetamist, mitte ei tekitaks lisatööd. Selline lähenemisviis eeldab, et Eesti haridussüsteemis toimivad tehnoloogiad peaksid olema koosvõimelised ning andmed liikuma standardiseeritud kujul, näiteks järgides xAPI standardit, nagu on soovitanud ka Tammets ja Laanpere (2015) Eesti haridussüsteemi jaoks õpianalüütika kontseptuaalse raamistiku loomisel.

Pädevuspõhist lähenemisviisi õpianalüütika lahenduse väljatöötamisel pidasid oluliseks kõik uuringus osalenud sidusrühmad. Võimalust saada ülevaadet õppija pädevuste kujunemisest nii õppekava kui ka eriala kontekstis väärtustasid uuringus osalenud üliõpilased, õppejõud ja õppekavade juhid kõrgelt. Ülevaadet õppematerjalidest, mida kaasõppijad õpikeskkonnas kasutasid, uuringus osalenud üliõpilased oluliseks ei pidanud, viidates siinkohal 
ennastjuhtiva õppija suutlikkusele ise sobivaid ja vajalikke õppematerjale leida. Tasub rõhutada, et uuritud üliõpilaste arvamus ei ole kooskõlas õppejõudude arvamusega, millele osutasid oma varasemas uurimuses Tammets ja Laanpere (2015). See võib tähendada, et vaatlusaluses etapis ei pruugi üliõpilased osata hinnata, millised töölaua vaated neile rohkem tuge pakuvad, ning seda tasub edasi uurida uuringu järgmises etapis.

Võtmeelemendiks õppijate enesereguleeritud õppimises on jooksev ja pidev tagasiside, kuna see toetab õppijaid õpieesmärkide saavutamisel, võimaldades analüüsida oma arengut ja kohandada õpistrateegiaid (Butler \& Winne, 1995; Macfadyen jt, 2014). Praeguses uuringus tõid kõik õpetajahariduse sidusrühmad õppimist toetava olulise vajadusena välja süsteemse ning aja- ja asjakohase tagasiside. Kui uuringus osalenud üliõpilased mõistsid individuaalse tagasiside vähesust, mis tuleneb suurest ajakulust, siis õppejõud ja õppekavade juhid rõhutasid vajadust välja töötada automatiseeritud tagasisidesüsteemid, mis toetaksid õpioskuste arengut. Samuti pidasid õppejõud oluliseks, et õppijatel oleksid oskused ja valmisolek keskkonnast saadavat tagasisidet analüüsida ning rakendada seda oma õpioskuste arendamiseks.

Varasemad uuringud ning digitaalsetes keskkondades katsetatud lahendused, mille keskmes on õppijate eneseregulatsiooni toetamine (Corrin \& de Barba, 2014; Laanpere jt, 2014; Põldoja jt, 2016a; Põldoja jt, 2016b; Väljataga jt, 2011), võimaldavad õppijal seada isiklikke õpieesmärke, annavad õppijatele tagasisidet nende edenemise kohta kursustel (sh saab seda teha õpimärkide abil) ning võimaldavad kasutada koostöist õppedisaini. Praeguses uuringus osalenud õpetajahariduse sidusrühmad õpianalüütika töölaua väljatöötamisel isiklike õpieesmärkide olulisust ei rõhutanud, kuid nad pidasid väga oluliseks tagasisidet õppekava ja eriala pädevuste kujunemise kohta. Siinkohal võib järeldada, et nii üliõpilased, óppejõud kui ka õppekavade juhid ei näe vajadust individuaalsete õpieesmärkide püstitamise järele ning peavad neist olulisemaks õppekava ja/või eriala pädevusi. Samuti selgus uuringust, et õpianalüütika võimalust saada ülevaade sotsiaalsest võrgustikust õpikeskkonnas ei pidanud vajalikuks ei uuringus osalenud üliõpilased ega õppejõud.

Uuringus osalenud üliõpilased ja õppejõud tõid mitmel puhul välja soovi, et õpianalüütika võimalused oleksid õpikeskkonda integreeritud, kuid õppija ja õppejõud peaks saama õpianalüütika võimalusi kasutada vaid soovi korral, sh neid ka välja lülitada. Samas on mitmed varasemad uuringud (Arnold \& Pistilli, 2012; Corrin \& de Barba, 2014) näidanud, et võimalus saada õpianalüütika rakendustelt tagasisidet ning võimalus pääseda ligi oma õpianalüütika töölaudadele parandavad õppijate õpitulemusi ja sooritusi, suurendavad õppija ja õpetaja suutlikkust reflekteerida ja planeerida oma õppetööd ning mõjuvad õppijatele motiveerivalt. 
Võimalust võrrelda enda tegevust (sooritused, tulemused jne) teiste õppijate omaga ei pidanud uuringus osalenud üliõpilased ja õppejõud väga oluliseks. Mõlema sidusrühma puhul leidis osa uuringus osalenutest, et võrdlus teistega võib õppijaid motiveerida, ning teine osa, et ennastjuhtiva õppija jaoks ei ole võrdlusmoment õppimise ajendiks. Samas osutavad varasemad uurimistulemused, et need õppijad, kes võrdlesid õpianalüütika võimaluste abil oma saavutusi ja tulemusi teiste õppijate omadega, saavutasid paremad õpitulemused kui need, kes õpianalüütika võimalusi ei kasutanud (Sclater jt, 2016). Seega tasub uuringu edasises etapis analüüsida, kuidas on seotud õpitulemuste võrdlust võimaldavate õpianalüütika rakenduste kasutajate ja mittekasutajate soorituse tase.

Uuringu puudusena võib välja tuua disainisessioonide korraldamise ainult ühes Eesti õpetajaharidust koordineerivas ülikoolis õppivate üliõpilaste, õpetavate õppejõudude ja õppekavade juhtide seas. Samas võimaldas ühes ülikoolis tehtud uuring kaasata eri haridustasemete (alushariduse, üldhariduse jne) õppekavadega seotud üliõpilasi ja õppejõude ning saadud andmestik oli mitmekesine ja piisav. Samuti võib uuringu puudusena nimetada eri õpihaldussüsteemide ja õpikeskkondade ekraanitõmmiste kasutamist disainisessioonides, sest selle tõttu võisid uuringus osalejad visuaalsesse külge liialt kinni jääda, suutmata näha laiemaid võimalusi õpianalüütika rakendamisel.

Uuringu järgmine etapp hõlmab õpikeskkonna eDidaktikum töölaudade esimeste sõrestike disaini, mille eesmärk on evalveerida ootused ja nõudmised, mis praeguses uuringus välja selgitati. Seejärel kavandatakse ja rakendatakse õpikeskkonnas õppeprotsess, mille järel analüüsitakse õppijate, õppejõudude ja õppekavade juhtide tagasisidet õpikeskkonda integreeritud õpianalüütika lahendustele.

\section{Kokkuvõte}

Tänapäeva õppijate õpikogemusi ja õppejõudude õpetamispraktikat mõjutab eri õpihaldussüsteemide ja õpikeskkondade kasutamine. Õpikeskkondadesse talletuvad digitaalsed andmed annavad õppijatele ja õppejõududele võimaluse saada tagasisidet oma õppimise ja õpetamise kohta. Õpianalüütika pakub laialdasi võimalusi suurendada õppijate teadlikkust oma õppimisest ja edenemisest ning annab õppejõududele võimaluse tõhustada õppeprotsessi.

Selles artiklis esitatud uuringus keskenduti õpetajahariduse üliõpilaste ja õppejõudude ootustele ning vajadustele seoses õpianalüütika töölaudadega, mis toetaksid ennastjuhtivat õppimist. Tulemused näitasid, et õppijad, õppejõud ning õppekavade arendamise ja rakendamise eest vastutajad näevad õpianalüütikas võimalust saada pidevat tagasisidet õppijate edenemise kohta 
eri- ja kutseala, õppekava ning aine tasandil, et seeläbi luua võimalusi toetada õppimist ja õpetamist, parandada õppeprotsessi ning arendada õppekava. Kui koostöine õppimine on ennastjuhtivas õppimises olulisel kohal, siis õpianalüütika võimaluste ülevaadet sotsiaalse suhtlemise võrgustikest tähtsaks ei peetud. Põhjendusena võib välja tuua suhtlemise väljaspool õpikeskkondi või muudes sotsiaalvõrgustikes.

Uuringu tulemusena pakutakse artiklis välja õppija autonoomsust, koostöist õppimist ning õppija pädevuste kujunemist toetavad õpianalüütika lahendused õpikeskkonnas.

\section{Kasutatud kirjandus}

Arnold, K. E., \& Pistilli, M. D. (2012). Course signals at Purdue: Using learning analytics to increase student success. Proceedings of the 2nd International Conference on Learning Analytics \& Knowledge. New York: ACM. https://doi.org/10.1145/2330601.2330666

Barab, S., \& Squire, K. (2004). Design-based research: Putting a stake in the ground. The Journal of the Learning Sciences, 13(1), 1-14. https://doi.org/10.1207/s15327809jls1301_1

Beyer, H., \& Holtzblatt, K. (1998). Contextual design: Defining customer-centered systems. San Francisco: Morgan Kaufmann.

Bichsel, J. (2012). Analytics in higher education: Benefits, barriers, progress, and recommendations (research report). Louisville: EDUCAUSE Centre for Applied Research. Retrieved from http://net.educause.edu/ir/library/pdf/ERS1207/ers1207.pdf.

Bransford, J. D., Brown, A. L., \& Cocking, R. R. (Eds.) (2000). How people learn: Brain, mind, experience, and school. Washington: National Academy Press.

Butler, D. L., \& Winne, P. H. (1995). Feedback and self-regulated learning: A theoretical synthesis. Review of Educational Research, 65(3), 245-281. https://doi.org/10.3102/00346543065003245

Corrin, L., \& de Barba, P. (2014). Exploring students' interpretation of feedback delivered through learning analytics dashboards. In B. Hegarty, J. McDonald, \& S.-K. Loke (Eds.), Rhetoric and reality: Critical perspectives on educational technology. Proceedings, ASCILITE, Dunedin 2014 (pp. 629-633).

Dunlosky, J., \& Thiede, K. W. (1998). What makes people study more? An evaluation of factors that affect self-paced study. Acta Psychologica, 98(1), 37-56. https://doi.org/10.1016/S0001-6918(97)00051-6

Durall, E., \& Gros, B. (2014). Learning analytics as a metacognitive tool. Proceedings of the 6th International Conference on Computer Supported Education CSEDU (pp. 380-384).

Hackos, J. T., \& Redish, J. C. (1998). User and task analysis for interface design. New York: Wiley.

Jonassen, D. H. (1991). Objectivism versus constructivism: Do we need a new philosophical paradigm? Educational Technology Research and Development, 39(3), 5-14. https://doi.org/10.1007/BF02296434 
Knight, D. B., Brozina, C., Stauffer, E. M., Frisina, C., \& Abel, T. (2015). Developing a learning analytics dashboard for undergraduate engineering using participatory design. Proceedings of the 122nd Annual Conference of the American Society for Engineering Education. https://doi.org/10.18260/p.23824

Krippendorff, K. (2006). Semantic turn: New foundations for design. Boca Raton, London: CRC Taylor \& Francis.

Kruger, J., \& Dunning, D. (1999). Unskilled and unaware of it: How difficulties in recognizing one's own incompetence lead to inflated self-assessments. Journal of Personality and Social Psychology, 77(6), 1121-1134. https://doi.org/10.1037/0022-3514.77.6.1121

Kujula, S., \& Mäntylä, M. (2000). How effective are user studies? In S. McDonald, Y. Waern, \& G. Cockton (Eds.), People and computers XIV (pp. 61-71). SpringerVerlag. https://doi.org/10.1007/978-1-4471-0515-2_5

Laanpere, M., Pata, K., Normak, P., \& Põldoja, H. (2014). Pedagogy-driven design of digital learning ecosystems. Computer Science and Information Systems, 11(1), 419-442. https://doi.org/10.2298/CSIS121204015L

Long, P., \& Siemens, G. (2011). Penetrating the fog: Analytics in learning and education. EDUCAUSE Review, 46(5), 31-40.

Loyens, S. M. M., Magda, J., \& Rikers, R. M. J. P. (2008). Self-directed learning in problem-based learning and its relationships with self-regulated learning. Educational Psychology Review, 20(4), 411-427.

https://doi.org/10.1007/s10648-008-9082-7

Macfadyen, L. P., \& Dawson, S. (2010). Mining LMS data to develop an "early warning system" for educators: A proof of concept. Computers \& Education, 54(2), 588-599. https://doi.org/10.1016/j.compedu.2009.09.008

Macfadyen, L. P., Dawson, S., Pardo, A., \& Gašević, D. (2014). Embracing big data in complex educational systems: The learning analytics imperative and the policy challenge. Research and Practice in Assessment, 9(2), 17-28.

Park, Y., \& Jo, I.-H. (2015). Development of the learning analytics dashboard to support students' learning performance. Journal of Universal Computer Science, 21(1), 110-133. https://doi.org/10.3217/jucs-021-01-0110

Pata, K., Tammets, K., Tomberg, V., Al Smadi, M., \& Laanpere, M. (2016). Three curriculum maturing cycles in academic curriculum management systems. In L. Uden \& D. Liberona (Eds.), Learning technology for education in Cloud: The changing face of education (pp. 1-12). Heidelberg: Springer. https://doi.org/10.1007/978-3-319-42147-6_24

Põldoja, H., Duval, E., \& Leinonen, T. (2016a). Design and evaluation of an online tool for open learning with blogs. Australasian Journal of Educational Technology, 32(2), 64-81. https://doi.org/10.14742/ajet.2450

Põldoja, H., Jürgens, P., \& Laanpere, M. (2016b). Design patterns for badge systems in higher education. In D. K. W. Chiu, I. Marenzi, U. Nanni, M. Spaniol, \& M. Temperini (Eds.), Advances in web-based learning - ICWL 2016 (pp. 40-49). Springer. https://doi.org/10.1007/978-3-319-47440-3_5

Roll, I., Wiese, E. S., Long, Y., Aleven, V., \& Koedinger, K. R. (2014). Tutoring selfand co-regulation with intelligent tutoring systems to help students acquire better learning skills. In R. Sottilare, A. Graesser, X. Hu, \& B. Goldberg (Eds.), Design 
recommendations for adaptive intelligent tutoring systems: Volume 2. Adaptive Instructional Strategies (pp. 169-182). Orlando: U.S. Army Research Laboratory.

Schuler, D., \& Namioka, A. (Eds.) (1993). Participatory design: Principles and the practices. Hillsdale: Lawrence Erlbaum Associates.

Sclater, N., Peasgood, A., \& Mullan, J. (2016). Learning analytics in higher education. A review of UK and international practice. Retrieved from https://www.jisc.ac.uk/sites/default/files/learning-analytics-in-he-v3.pdf.

Tammets, K., \& Laanpere, M. (2015). Õpianalüütika kontseptuaalne raamistik ja selle rakendatavus Eesti kontekstis. Eesti Haridusteaduste Ajakiri, 3(2), 216-246. https://doi.org/10.12697/eha.2015.3.2.08

Verbert, K., Duval, E., Klerkx, J., Govaerts, S., \& Santos, J. L. (2013). Learning analytics dashboard applications. American Behavioral Scientist, 57(10), 1500-1509. https://doi.org/10.1177/0002764213479363

Väljataga, T., Tammets, K., \& Põldoja, H. (2011). Competence development of preservice teachers with the support of LeContract. In I. Aedo, N.-S. Chen, D. G. Sampson, J. M. Spector, \& Kinshuk (Eds.), 2011 IEEE 11th International Conference on Advanced Learning Technologies (pp. 611-612). Athens: IEEE Computer Society. https://doi.org/10.1109/ICALT.2011.186

Wolf, P. (2007). A model for facilitating curriculum development in higher education: A faculty-driven, data-informed, and educational developer-supported approach. New Directions for Teaching \& Learning, 112, 15-20. https://doi.org/10.1002/tl.294 


\title{
Opportunities for learning analytics supporting learning and teaching in teacher education
}

\author{
Kaire Kollom ${ }^{\text {a1 }}$, Kairit Tammets ${ }^{\mathrm{b}}$ \\ a School of Educational Sciences, Tallinn University \\ ${ }^{b}$ School of Digital Technologies, Tallinn University
}

\begin{abstract}
Summary
Most studies of learning analytics have so far focused mainly on higher education students, but recently also on how the learning analytics dashboard could provide feedback for the learners' learning process. Macfayden et al. (2014) have said that automated analytics provided for teachers and learners is not only supporting learners' academic performance, but also shapes the skills of self-directed learning which has been considered as a significant factor to academic success. Self-directed learning and its promotion of the learning analytics dashboard is also the focus of the current article. Learning analytics dashboards have been an interest of several researchers for several years, but there is a lack of studies that demonstrate how learners interpret the learning analytics dashboard visualizations and how such visualizations change the learning behaviour: goal setting, planning, reflecting etc., because such evaluations are time-consuming and require a longitudinal research approach. There is a lack of evidence and little research to indicate which monitoring variables may be pedagogically meaningful (Macfayden \& Dawson, 2010). Additionally few attempts have been made to study how learning analytics and its visualizations can be used in the curriculum development process and evidence-based decision making in higher education, especially in teacher education. The aim of the paper is to investigate the expectations and needs of the learning analytics dashboards for teacher education with the aim to enhance the student's self-directed learning competencies. Research questions of the study were formulated as follows:

- What kinds of learning analytics dashboard visualizations are meaningful for the pre-service teachers to support self-directed learning?

- How do the teacher educators perceive the learning analytics dashboard visualizations as a tool to support teachers' self-directed learning?
\end{abstract}

School of Educational Sciences, Tallinn University, Uus-Sadama 5, 10120 Tallinn, Estonia; kaire.kollom@tlu.ee 
- What kind of possibilities can learning analytics dashboards provide for supporting the enhancement of research-based interventions in Estonian teacher education?

Research design follows the principles of design-based research (DBR) (Barab \& Squire, 2004) because DBR is a flexible framework which aims to improve educational practices through iterative design, analysis, development and evaluation phases in collaboration with the researchers and practitioners. Practitioners in the current study are different stakeholders from the teacher education context. Involving stakeholders in the design process enables researchers to better understand the research context and needs of the users. In order to better understand the needs and expectations related to the learning analytics dashboard, participatory design sessions were carried out with the nine pre-service teachers, five teacher educators, and five curriculum heads.

The study shows that students, academic staff and also curriculum leaders who oversee the development and implementation of the curricula believe that the most important thing when using online environments is that the learning environments and learning systems communicate and exchange data. All the participants stated that using online learning environments should support learning and teaching and not cause extra work. The research found that getting an overview on the development of student competencies both in curriculum form and speciality context is important for students, academic staff and curriculum designers.

Developing learning analytics solutions teacher training stakeholders considered it important that the environments should enable a systematic and time appropriate feedback that would support the learner. Although the students stated that they understood the scarcity of individual feedback which is due to the lack of time, the academic staff and curriculum leaders stressed that the learning outcome based on automated feedback systems should be developed. Furthermore, the academic staff considered it important that the students should have the skills and abilities to analyse the feedback that they experienced from the online environments and thus implement it to enhance learning skills development.

The students and academic staff brought out multiple times that learning analytics solutions should be integrated into the online environments although the option of using learning analytics should be optional, and they should offer the opportunity to compare learners' own activities, including performance, results etc. With other students, it was not considered important by the students and academic staff. A section of both research groups found that it would be motivating, but others stated that for a self-directed learner, comparison with others is not important to learning. 
The initial results from the learners, lecturers and heads of curricula indicated that for supporting the autonomy of learners the system should:

- Provide an overview for the learner about the progress and performance of the course context;

- Give an opportunity to compare ones' own progress, achievements and the results with the rest of the study group;

- Enable to analyze the correlation between self-evaluated efforts (time spent, degree of the difficulty) and results of the learning activity;

- The development process of the competencies defined in the qualification standard at the individual, group and curriculum level.

The study showed that all participants agreed that working together and collaboration were extremely important. At the same time, they stated that an overview of social interactions in learning analytics is not considered important rather than the online environment should have a wide range of technological solutions, for example limiting the number of participants.

The participants of the study stated that the development and student competencies and the possibility of comparing the learning results with the groups overall average are considered important in learning, teaching, curriculum design and implementation and also in learning design.

Expectations on learning analytics solutions are as follows:

- Creating a course in the learning environment should have the option of integrating subject based and speciality standard learning outcomes;

- An overview and group average comparing;

- The opportunity to view student competencies development individually, on the basis of a learning group and across the curriculum.

The next phase of the study will focus on the design of dashboards together with the students, lecturers and head of the curricula with the aim of validating the needs and expectations defined in the current study.

Keywords: learning analytics, self-directed learner, learning environment, teacher training, academic staff 